\title{
Analisis Pengaruh Budaya Organisasi dan Sistem Tanggung Renteng terhadap Perilaku Anggota yang berdampak kepada Keamanan Usaha di Koperasi Setia Budi Wanita Malang
}

\author{
Savitri Sartono ${ }^{1}$, Harianto Respati ${ }^{2}$ \\ ${ }^{12}$ Universitas Merdeka Malang \\ Email : savitri2563@gmail.com
}

\begin{abstract}
This research examines, analyzes, and examines the influence of organizational culture and shared responsibility systems on member behavior that impacts on business security in the Setia Budi Wanita Cooperative (SBW) Malang, East Java, Indonesia. Researchers are interested in examining this by seeing that there is something unique and great in the SBW Malang Cooperative in terms of organizational culture, shared responsibility systems, member behavior, and business security so that researchers consider it necessary to conduct research to determine the influence of organizational culture and systems joint responsibility for member behavior that impacts on business security in the Malang SBW Cooperative. This research is quantitative research. The type of data used is the type of quantitative data derived from qualitative data in the form of a questionnaire to 127 quantified respondents. Primary data obtained directly from the field, sourced from respondents members of the Malang SBW Cooperative, in the form of statements about the variable system of shared responsibility for the behavior of members. Observations were made by observing office operational processes and member services, as well as visits to several group meetings. In addition, researchers also conducted data mining in the form of interviews with parties related to this research. Secondary data were obtained from documentation, reference books, and information related to this research. The independent variables in this study are organizational culture and shared responsibility systems. The dependent variable in this study is member behavior and business security. Descriptive Data Analysis Techniques use the Mean and Mode statistical tools to explain respondents' perceptions. Data analysis uses Structural Equation Modeling (SEM). Hypothesis testing uses path analysis.The results of this study indicate that there is a significant influence between organizational culture and shared responsibility systems on member behavior and there is a significant influence between member behavior and business security. Researchers found that organizational culture, in this case the culture of cooperation applied to the system of shared responsibility in the form of group meetings, dominantly shaped the behavior of members. A strong organizational culture and proper and proper joint system implementation make members behave well. Positive behavior of members manifested in the willingness to take care of, then contribute, and participate in cooperatives has an impact on business security which can be seen from the transparency of business development, assets, and business results remaining and financial ratios. The key to success in realizing business security is the existence of a strong organizational culture in this case the gotong culture which is realized in the implementation of a shared responsibility system properly and correctly, transparent management, so that the formation of positive, honest, and open. member behavior.
\end{abstract}

Keywords: Culture of cooperation, honesty, transparency, business security

Abstrak

Penelitian ini bertujuan untuk mengetahui Pengaruh Motivasi terhadap Kinerja Karyawan PT. PLN (Penelitian ini mengkaji, menganalisis, dan mengetahui pengaruh budaya organisasi dan sistem tanggung renteng terhadap perilaku anggota yang berdampak kepada keamanan usaha di Koperasi Setia Budi Wanita (SBW) Malang Jawa Timur, Indonesia. Peneliti tertarik untuk meneliti hal ini dengan melihat bahwa ada hal yang unik dan besar di Koperasi SBW Malang ini dalam sisi budaya organisasi, sistem tanggung renteng, perilaku anggota, dan keamanan usahanya sehingga Peneliti memandang perlu melakukan penelitian untuk mengetahui pengaruh budaya organisasi dan sistem tanggung renteng terhadap perilaku anggota yang berdampak kepada keamanan usaha di Koperasi SBW Malang. Penelitian ini adalah penelitian kuantitatif. Jenis data yang digunakan adalah jenis data kuantitatif yang berasal dari data kualitatif berupa angket kepada 127 responden yang dikuantitatifkan. Data primer yang diperoleh langsung dari lapangan, bersumber dari responden anggota Koperasi SBW Malang, berupa pernyataan tentang variabel sistem tanggung renteng terhadap perilaku 
anggota. Observasi dilakukan dengan mengamati proses operasional kantor dan pelayanan anggota, serta kunjungan di beberapa pertemuan kelompok. Di samping itu Peneliti juga melakukan penggalian data dalam bentuk wawancara kepada pihak-pihak yang terkait dengan penelitian ini. Data sekunder diperoleh dari dokumentasi, buku-buku referensi, dan informasi yang berhubungan dengan penelitian ini. Variabel bebas pada penelitian ini adalah budaya organisasi dan sistem tanggung renteng. Variabel terikat pada penelitian ini adalah perilaku anggota dan keamanan usaha. Teknik Analisis Data secara deskiptif menggunakan alat statistik Mean dan Modus untuk menjelaskan persepsi responden. Analisis data menggunakan model Persamaan Struktural (Structural Equation Modelling/SEM). Uji hipotesis menggunakan analisis jalur. Hasil penelitian ini menunjukkan bahwa ada pengaruh yang signifikan antara budaya organisasi dan sistem tanggung renteng terhadap perilaku anggota dan ada pengaruh yang siginifikan antara perilaku anggota dan keamanan usaha. Peneliti menemukan bahwa budaya organisasi dalam hal ini budaya gotong royong yang diaplikasikan ke dalam sistem tanggung renteng dalam bentuk pertemuan kelompok secara dominan membentuk perilaku anggota. Budaya organisasi yang kuat dan penerapan sistem tanggung renteng dengan benar dan baik membuat anggota berperilaku dengan baik. Perilaku anggota yang secara positif terwujud dalam kesediaan turut menjaga, kemudian berkontribusi, dan berpartipasi terhadap koperasi berdampak terhadap keamanan usaha yang bisa dilihat dari adanya tranparansi perkembangan usaha, asset, dan sisa hasil usaha serta rasio-rasio keuangan. Kunci keberhasilan dalam mewujudkan keamanan usaha adalah adanya budaya organisasi yang kuat dalam hal ini budaya gotong yang diwujudkan dalam aplikasi sistem tanggung renteng dengan benar dan baik, manajemen yang transparan, sehingga terbentuknya perilaku anggota yang positif, jujur, dan terbuka.

Kata Kunci : Budaya Gotong Royong, Kejujuran, Transparansi, Keamanan usaha

\section{(C) 2021 Jurnal Riset Inspirasi Manajemen dan Kewirausahaan}

\section{PENDAHULUAN}

Dunia bisnis dan ekonomi dewasa ini Budaya organisasi merupakan sistem penyebaran kepercayaan dan nilai-nilai yang berkembang dalam suatu organisasi dan mengarahkan perilaku anggota-anggotanya. Menurut Mangkunegara (2005), budaya organisasi adalah seperangkat asumsi atau sistem keyakinan, nilai-nilai, dan norma yang dikembangkan dalam organiasi yang dijadikan pedoman tingkah laku bagi anggotaanggotanya untuk mengatasi masalah adaptasi eksternal dan internal. Budaya harus sejalan dengan tindakan organisasi pada bagian lain seperti perencanaan, pengorganisasian, kepemimpinan, dan pengendalian (Revai, 2011). Budaya Organisasi berkaitan sangat erat dengan komitmen organisasi, dimana suatu organisasi/perusahaan memiliki nilai-nilai bersama yang dianut oleh anggota dalam organisasi/perusahaan tersebut yang menjadi ciri khas berbeda dengan organisasi/perusahaan lain. Budaya organisasi menjadi kepribadian organisasi yang mempengaruhi cara bertindak individu dalam organisasi. Di dalam realita, budaya organisasi ada yang kuat dan ada juga budaya organisasi yang lemah.

Tanggung renteng adalah sebuah istilah dalam hutang piutang yang bermakna tanggung menanggung. Sistem tanggung renteng yang ada di koperasi adalah sebuah tatanan berkoperasi yang di dalamnya merupakan tanggung jawab bersama anggota di satu kelompok atas segala kewajibannya terhadap koperasi atas dasar keterbukaan dan saling mempercayai mewujudkan wadah interaksi manusia yang dialogis menuju manusia berkualitas. Sistem tanggung renteng berjalan dalam koperasi melalui keanggotaan koperasi yang ditata dalam kelompok-kelompok anggota. Sistem ini berfungsi sebagai tata nilai dan sistem di dunia koperasi, khususnya koperasi simpan pinjam. Sebagai tata nilai, sistem tanggung renteng terwujud dalam kesalingpercayaan, musyawarah, kebersamaan, keterbukaan, dan tanggung jawab. Sistem tanggung renteng mendorong pencapaian tujuan koperasi secara kolektif.

Perilaku manusia adalah semua kegiatan atau aktivitas manusia, baik yang diamati langsung, maupun yang tidak dapat diamati oleh pihak luar (Notoatmodjo, 2003). Perilaku bisa terbentuk sebagai suatu proses dinamika dalam lingkungan tertentu. Kehidupan sosial dalam kelompok dengan tujuan hidup yang homogen dapat membentuk sebuah perilaku bersama yang menunjukkan identitas dari kelompok dan anggotanya.

Koperasi akan berkembang bila dikelola dengan manajemen yang profesional berdasarkan nilai-nilai dalam koperasi, (Ibnoe Soedjono, 2001). Indikator untuk menilai keberhasilan dan keamanan usaha koperasi diantaranya meliputi Aspek permodalan, Kualitas Aktiva Produktif, Manajemen, Efisiensi, Likuiditas, Kemandirian dan Pertumbuhan, dan Jatidiri Koperasi yang terdiri 
dari definisi, nilai-nilai, dan prinsip-prinsip koperasi, (Ibnoe Soedjono 1997).

Di Jawa Timur telah cukup banyak koperasi yang berhasil. Salah satunya adalah Koperasi Setia Budi Wanita Malang Jawa Timur (Koperasi SBW Malang), yang telah mantap secara ekonomi dan telah mampu menjalankan bidang ekonomi, sosial, dan budaya dalam kehidupan berkoperasi. Koperasi SBW Malang yang sudah berkembang ini memiliki budaya inti organisasi yaitu budaya gotong royong. Budaya gotong royong ini diimplementasikan dalam sistem tanggung renteng. Dalam sistem ini, anggota dibagi dalam kelompok-kelompok anggota yang diatur dengan sedemikian rupa sehingga tercipta kehidupan berkelompok yang kuat menjadi sebuah tingkatan manajemen tersendiri dalam berkoperasi, dimana anggota menerima banyak pembelajaran tentang nilai-nilai koperasi, prinsipprinsip koperasi, nilai-nilai gotong royong, serta nilai dan prinsip sistem tanggung renteng.

Dari uraian di atas, peneliti melihat bahwa tentu ada hal yang unik dan besar di Koperasi SBW Malang ini dalam sisi budaya organisasi, sistem tanggung renteng, perilaku anggota, dan keamanan usahanya. Untuk itulah Peneliti memandang perlu melakukan penelitian untuk mengetahui pengaruh budaya organisasi dan sistem tanggung renteng terhadap perilaku anggota yang berdampak kepada keamanan usaha di Koperasi SBW Malang. Penelitian ini ingin mengetahui gambaran tentang budaya organisasi, sistem tanggung renteng, perilaku anggota, dan keamanan usaha, sejauh mana pengaruh antara budaya organisasi dan sistem tanggung renteng terhadap perilaku anggota, dan mengetahui gambaran tentang perilaku anggota memberikan dampak terhadap keamanan usaha di Koperasi SBW Malang.

\section{KAJIAN LITERATUR}

\section{Pengertian Koperasi}

Istilah koperasi berasal dari bahasa asalnya cooperation (Latin) yaitu sebuah sistem kerja sama yang berdasarkan prinsip kebersamaan dan kekeluargaan. Koperasi lahir sebagai identitas kerja sama sekelompok orang yang memiliki tujuan ekonomi, sistem kerja, aturan pengelolaan dan format keorganisasian yang jelas. Azas koperasi yaitu yang pertama, koperasi bertujuan untuk memenuhi kebutuhan anggotanya. Dalam mencapai tujuannya koperasi tetap memiliki orientasi ekonomi, mendapatkan keuntungan, tetapi tetap berada dalam tujuannya yang utama. Kedua, koperasi mengemban fungsi sosial dan lebih mengutamakan keberpihakan kepada masyarakat miskin. Koperasi antar koperasi d harus selalu saling membantu dan mendukung. Ketiga, koperasi merupakan persekutuan independen yang merdeka dan tidak lahir atas tekanan atau paksaan. Rekruitmen keanggotaan dalam koperasi tidak terdapat unsur paksaan dan anggota dibiarkan untuk bebas memilih. Koperasi merupakan bentuk usaha yang dijalankan berdasar asas kekeluargaan dan kerja sama.

\section{International}

Cooperative Alliance (ICA) di Manchester, Inggris, 23 September 1995 telah merumuskan Jatidiri Koperasi yang dikenal dengan nama ICIS (ICA Cooperative Identity Statements). Isinya ada tiga kesatuan tak terpisah yaitu Definisi, Nilai, dan Prinsip Koperasi yang di Indonesia disosialisasikan dengan istilah Jati Diri Koperasi (Soedjono, 1997). Definisi Koperasi adalah perkumpulan otonom dari orang-orang yang bersatu secara sukarela untuk memenuhi kebutuhan-kebutuhan dan aspirasiaspirasi ekonomi, sosial, dan budaya bersama melalui perusahaan yang mereka miliki bersama dan mereka kendalikan secara demokratis. Nilainilai Koperasi berlandaskan nilai-nilai menolong diri sendiri, tanggung jawab pribadi, demokrasi, persamaan, keadilan dan kesetiakawanan. Mengikuti tradisi para pendirinya, anggota - angota koperasi percaya pada nilai - nilai etis dari kejujuran, keterbukaan, tanggung jawab sosial serta kepedulian terhadap orang-orang lain. Prinsipprinsip Koperasi terdiri dari keanggotaan sukarela dan terbuka, pengendalian oleh anggota secara demokratis, partisipasi ekonomi anggota, otonomi dan kebebasan, pendidikan, pelatihan, dan nformasi, kerjasama di antara koperasi, serta kepedulian terhadap masyarakat. (ICA. 1995).

Fungsi aggota dalam koperasi adalah sebagai pemilik, pengguna, dan pemeran serta. Anggota sebagai pemilik adalah fungsi anggota sebagai pemilik saham koperasinya dalam bentuk simpanan pokok dan simpanan wajib yang memiliki kewajiban untuk serta mengendalikan kehidupan koperasinya secara demokratis sesuai dengan aturan-aturan yang diatur dalam Anggaran Dasar, Anggaran Rumah Tangga, dan Peraturan-peraturan lainnya yang berlaku. Kepemilikan anggota berimplikasi terhadap kepemilikan hak suara di dalam Rapat Anggota. Kepemilikan hak satu suara bagi satu anggota tidak dipengaruhi oleh jumlah modal yang ditanamkan maupun usia keanggotaannya. Pengertian fungsi anggota sebagai pengguna adalah anggota sebagai penerima manfaat dari keberadaan koperasi. Anggota adalah pasar utama yang riil dari semua produk-produk koperasi. Prioritas utama pengguna produk-produk koperasi adalah seluruh anggotanya. Setelah anggota menerima manfaat dari koperasinya, maka 
barulah melayani masyarakat sekitar dengan harapan masyarakat juga bisa menjadi anggota. Sedangkan fungsi anggota sebagai pemeran serta mengandung arti bahwa anggota adalah partisipan yang membawa kemajuan maupun kemunduran koperasinya. Tingkat keaktifan anggota untuk berpartisipasi terhadap koperasinya sangat menentukan kemajuan maupun kemunduran koperasi.

Pengembangan koperasi di kalangan kaum wanita merupakan salah satu program dalam pembangunan, dimana koperasi adalah wadah yang sesuai dan sangat bisa diterima oleh kaum perempuan. Munkner menerangkan bahwa berdasarkan konsep yang jelas dan visi yang realistis mengenai peranan koperasi dalam masyarakat, gerakan koperasi dapat melanjutkan peranannya dalam pembangunan (Hans $\mathrm{H}$ Munkner, 1997).

\section{Budaya Organisasi}

Menurut Pandi (2018:2) Fungsi dari Budaya organisasi merupakan sistem penyebaran kepercayaan dan nilai-nilai yang berkembang dalam suatu organisasi dan mengarahkan prilaku anggota-anggotanya. Budaya organisasi akan menjadi ciri khas sebuah organisasi sehingga bisa membedakan dirinya dengan organisasi lain. Salah satu budaya organisasi yang ada adalah budaya gotong royong yang merupakan saripati dari nilainilai Pancasila. Lima sila dari Pancasila, disarikan dari pidato Bung Karno 1 Juni 1945, bisa diperas menjadi tiga sila saja yaitu socio-nationalisme, socio-democratie, dan ketuhanan. Dari tiga itu bisa diperas lagi menjadi satu yaitu gotong-royong. Gotong-royong sebagai solidaritas sosial yang terjadi dalam kehidupan masyarakat, terutama mereka yang membentuk komunitas-komunitas, karena dalam komunitas seperti ini akan terlihat dengan jelas. Istilah gotong royong berasal dari bahasa Jawa.

Gotong berarti pikul atau angkat, sedangkan royong berarti bersama-sama. Sehingga jika diartikan secara harafiah, gotong royong berarti mengangkat secara bersama-sama atau mengerjakan sesuatu secara bersama-sama. Gotong royong dapat dipahami pula sebagai bentuk partisipasi aktif setiap individu untuk ikut terlibat dalam memberi nilai positif dari setiap obyek, permasalahan, atau kebutuhan orang-orang di sekelilingnya. Gotong royong merupakan ciri khas bangsa Indonesia, yang membentuk perilaku sosial yang nyata membentuk tata nilai kehidupan sosial. Adanya nilai tersebut menyebabkan gotong royong selalu terbina dalam kehidupan komunitas sebagai suatu warisan budaya yang patut dilestarikan.
Gotong royong menganut prinsip keseimbangan antara kewajiban dan hak. Di dalam gotong royong tidak ada kata pamrih, asas kekeluargaan diterapkan, keseimbangan antara kewajiban dan hak terasa sebagai suatu hal yang asasi (Sosrodihardjo, 2001). Proses partisipasi spontan merupakan salah satu bentuk dalam gotong royong (Gurniwan, 1987). Selanjutnya, terdapat pula nilai-nilai kerja bakti dan tolongmenolong dalam kegiatan gotong-royong, tentu saja karena kerja bakti dan tolong-menolong menjadi bagian dari gotong royong yang dapat dilakukan untuk meringankan pekerjaan atau kegiatan (Bintarto, 1980).

Gotong royong menyimpan berbagai nilai positif, antara lain:

1. Kebersamaan

Gotong royong membuat masyarakat mau bekerja secara bersama-sama untuk membantu orang lain atau untuk membangun fasilitas yang bisa dimanfaatkan bersama.

2. Persatuan

Kebersamaan yang terjalin dalam gotong royong sekaligus melahirkan persatuan antar anggota masyarakat sehingga menjadi lebih kuat dan mampu menghadapi permasalahan yang muncul.

3. Rela berkorban

Pengorbanan tersebut dapat berkorban waktu, tenaga, pemikiran, hingga uang. Semua pengorbanan tersebut dilakukan demi kepentingan bersama, rela mengesampingkan kebutuhan pribadinya untuk memenuhi kebutuhan bersama.

4. Tolong menolong

Masyarakat saling bahu-membahu untuk menolong satu sama lain. Sekecil apapun kontribusi seseorang dalam gotong royong, selalu dapat memberikan pertolongan dan manfaat untuk orang lain.

5. Sosialisasi

Gotong royong membuat masyarakat saling mengenal satu sama lain sehingga proses sosialisasi dapat terus terjaga keberlangsungannya.

\section{Sistem Tanggung Renteng}

Dalam kehidupan berkoperasi, penerapan budaya gotong royong bisa ditemukan di dalam penerapan sistem tanggung renteng. Sistem tanggung renteng adalah tanggung jawab bersama di antara anggota atas kewajibannya terhadap koperasi mewujudkan wadah interaksi secara dialogis menuju manusia yang berkualitas (Untari, Sri \& Dewanto, Deddy Satya. 2008). Tanggung 
renteng mendorong lahirnya sistem yang menjamin tujuan koperasi dapat tercapai secara kolektif (kopkuninstitute.org/portofolio, 2016).Pelaksanaan sistem tanggung renteng di koperasi senantiasa berusaha membuat keseimbangan capaian antara bisnis berupa amannya aset dan dan perubahan perilaku manusia dengan konsekuensi berupa pengembangan sumber daya manusia koperasi. Dalam pelaksanaan sistem tanggung renteng, Pengurus harus menyadari bahwa koperasi merupakan jaringan yang bisa dikembangkan, sehingga pengurus sebagai pengendali koperasi harus memahami konsep dan aplikasi sistem tanggung renteng yang merupakan implementasi dari jatidiri koperasi (Indriyo, 2006).

Sistem tanggung renteng membagi tanggung jawab secara merata dan menerapkan konsep kolektifitas. Sistem tanggung renteng memiliki keterkaitan erat dengan budaya gotong royong seperti yang dinyatakan oleh Dewanto \& Sonhaji, "With gotong royong core culture, SBW Malang Cooperative managed to run its business using the tanggung renteng system. (Dewanto, Sonhaji, 2018)

\section{Perilaku}

Pada dasarnya bentuk perilaku dapat diamati, melalui sikap dan tindakan, dapat pula bersifat potensial, yakni dalam bentuk pengetahuan, motivasi dan persepsi. Perilaku manusia adalah semua kegiatan atau aktivitas manusia, baik yang diamati langsung, maupun yang tidak dapat diamati oleh pihak luar (Notoatmodjo, 2003). Perilaku Individu juga merupakan proses kerjasama antara sekelompok orang untuk mencapai tujuan yang telah ditetapkan, (Wursanto, 2003). Bentuk perilaku dilihat dari sudut pandang respon terhadap stimulus, maka perilaku dapat dibedakan menjadi dua yaitu perilaku tertutup, dimana respon atau reaksi terhadap stimulus ini masih terbatas pada perhatian, persepsi, pengetahuan/kesadaran, dan sikap yang terjadi belum bisa diamati secara jelas oleh orang lain. Selanjutnya adalah perilaku terbuka, dimana respon terhadap terhadap stimulus sudah jelas dalam bentuk tindakan atau praktek. Proses pembentukan perilaku dipengaruhi oleh beberapa faktor yang berasal dari dalam diri individu itu sendiri, faktor-faktor tersebut antara lain persepsi, motivasi, emosi, dan pembelajaran. Sedangkan belajar merupakan suatu perubahan perilaku yang dihasilkan dari perilaku terdahulu.

Perilaku manusia terjadi melalui suatu proses yang berurutan. Sebelum orang mengadopsi perilaku baru, di dalam diri orang tersebut terjadi proses yang berurutan meliputi kesadaran, ketertarikan, pertimbangan, percobaan, dan adopsi dimana orng telah berperilaku baru sesuai dengan pengetahuan, kesadaran, dan sikapnya terhadap stimulus. Berdasar uraian tentang perilaku ini, anggota di dalam koperasi sebagai seorang individu tentu juga memiliki perilaku tersendiri yang bisa dipengaruhi oleh kondisi lingkungan sekitarnya.

\section{Keamanan Usaha}

Kondisi usaha suatu organisasi bisa dilihat dari dari tren perkembangan asset, hutang, dan permodalan setidaknya selama 3 sampai 5 tahun terakhir. Untuk bisa mengetahui hal tersebut sangat akurat apabila melihatnya dari tren analisis rasio keuangan. Analisis rasio keuangan sangat penting untuk mengetahui bagaimana perkembangan suatu usaha.

\section{METODE PENELITIAN}

\section{Desain Penelitian}

Lokasi sekaligus obyek penelitian ini adalah Koperasi SBW Malang di jalan Raden Intan Kav. 108 Arjosari, Blimbing, Kota Malang Jawa Timur 65126. Penelitian ini menggunakan metode penelitian kuantitatif. Jenis data yang digunakan dalam penelitian adalah jenis data kuantitatif yang berasal dari data kualitatif berupa angket ke responden yang dikuantitatifkan agar dapat diproses menggunakan statistik. Dalam penelitian ini telah disebar sebanyak 127 angket dan telah diterima kembali secara keseluruhan sehingga bisa dilakukan proses analisis statistiknya.

\section{Populasi dan Sampel}

Data primer yang diperoleh langsung dari lapangan, bersumber dari responden yang merupakan anggota sekaligus sebagai Penanggung Jawab Kelompok di Koperasi SBW Malang, berupa pernyataan tentang variabel sistem tanggung renteng terhadap perilaku anggota. Responden untuk mengisi angket kuesioner di dalam penelitian ini adalah anggota yang berstatus sebagai Penanggungjawab Kelompok. Responden ini ini dipilih karena sebagai Penanggung Jawab Kelompok usia keanggotaan mereka di Koperasi SBW Malang dipastikan sudah lebih dari 3 tahun sehingga sudah memiliki pengalaman, pengetahuan, dan pemahaman yang cukup untuk mencerna dengan seksama kuesioner yang diajukan dalam penelitian ini. Setiap Penanggung Jawab Kelompok bertanggung jawab terhadap anggota kelompok yang berjumlah minimal 15 orang dan maksimal 55 orang. Berdasarkan hasil perhitungan metode Slovin, ditentukan jumlah sampel untuk mengisi angkrt sebanyak 127 orang untuk mewakili 9.645 orang anggota. Observasi dilakukan dengan 
mengamati proses operasional kantor dan pelayanan anggota, serta kunjungan di beberapa pertemuan kelompok, yaitu di kelompok 275, 175, 225 dan kelompok 189 yang dari observasi kunjungan kelompok itu bisa diambil gambaran terkait budaya organisasi, sistem tanggung renteng, dan operasional usaha koperasi dalam kehidupan kelompok. Di samping itu Peneliti juga melakukan penggalian data dalam bentuk wawancara kepada pihak-pihak yang terkait dengan penelitian ini meliputi Pengurus, Pengawas, Koordinator Usaha, Kepala Learning Center, Pembinan Pendamping Lapangan, Sekretariat. Data sekunder diperoleh dari dokumentasi, buku-buku referensi, dan informasi yang berhubungan dengan penelitian ini. Peneliti melakukan kajian terhadap Laporan Pertanggungjawaban Pengurus yang sudah disahkan dalam Rapat Anggota mulai tahun 2014 sampai dengan tahun 2018, dokumen-dokumen kelengkapan anggota, modul-modul pelatihan, dan buku-buku terkait, sehingga bisa diperoleh gambaran yang utuh tentang Koperasi SBW Malang.

\section{Teknik Analisis Data}

\section{Structural Equation Modelling (SEM)}

Pengolahan statistik pada penelitian kali ini menggunakan SEM. Tahapan analisis SEM sendiri setidaknya harus melalui lima

tahapan (Latan,2013:42-69) yaitu:

1. Spesifikasi model

Kegiatan pada langkah ini adalah mengembangkan suatu model berdasarkan kajian-kajian teoritik untuk mendukung penelitian terhadap masalah yang dikaji. Selanjutnya mendefinisikan model tersebut secara konseptual konstruk yang akan diteliti serta menentukan dimensionalitasnya. Arah hubungan yang dihipotesiskan pun haruslah jelas dan memiliki landasan teori.

2. Identifikasi model

Tahap ini merupakan tahap yang penting dalam SEM, karena model yang tidak dapat diidentifikasi, akan menjadi tidak dapat diestimasi atau dihitung. Penting bagi peneliti melakukan tahap ini guna mengetahui apakah model tersebut memiliki nilai unik atau tidak.Identifikasi ini dengan menghitung derajat kebebasan, dan nilai derajat kebebasan harus positif. Idealnya, setelah spesifikasi dan identifikasi model, tahap selanjutnya adalah penetuan jumlah sampel.
3. Estimasi model

Setelah data terkumpul, model diestimasi, setelah sebelumnya ditentukan metode estimasinya. Umumnya metode estimasi yang dipakai adalah maximum likelihood (ML).

4. Evaluasi model

Kegiatan pada langkah ini adalah mengevaluasi dan interpretasi hasil analisis. Tahap ini bertujuan untuk mengevaluasi model secara keseluruhan. Proses ini diawali dengan uji normalitas data selanjutnya dilanjutkan dengan menguji model pengukuran (measurement model) dengan menganalisis faktor konfirmasi untuk menguji validitas serta reliabilitas variabel laten, dilanjutkan dengan menguji structural model serta terakhir menilai overall fit model dengan mengacu pada goodness of fit (GoF).

5. Modifikasi model

Kegiatan ini berkenaan dengan hasil evaluasi dan interpretasi model. Jika dari nilai GoF model tersebut tidak atau belum fit, maka perlu dilakukan modifikasi atau respesifikasi model.

\section{HASIL PENELITIAN DAN PEMBAHASAN}

\section{Hasil Uji Model Persamaan Struktural}

Hasil uji model persamaan struktural adalah sebagai berikut :

$$
\begin{aligned}
\mathrm{Rm}^{2} \text { model } & =1-\left(\sqrt{1-R^{2}} \cdot \sqrt{1-R^{2}}\right) \\
& =1-(\sqrt{1-0,48} \cdot \sqrt{1-0,47}) \\
& =1-(\sqrt{0,62} \cdot \sqrt{0,63}) \\
& =1-(0,78 \cdot 0,79) \\
& =1-0,622 \\
& =0,37 .
\end{aligned}
$$

Nilai koefisien determinasi total sebesar 0,37 menunjukkan keragaman data atau informasi yang dapat dijelaskan oleh model tersebut sebesar $37,0 \%$. Sedangkan $63,0 \%$ dapat dijelaskan oleh variabel lain yang belum terdapat dalam model tersebut atau error. Penjelasan ini memberi makna bahwa model dalam penelitian ini diterima sebagai alat analisis yang teruji dan mampu membuat hipotesis yang dibuat. 
Analisa Jalur

Berdasarkan pengolahan data statistik, maka didapatkan perhitungan analisis jalur seperti di dalam tabel berikut :

Tabel 1

Ringkasan Hasil Analisis Jalur

\begin{tabular}{|c|c|c|c|}
\hline Variabel & $\begin{array}{l}\text { Pengaruh } \\
\text { Langsung }\end{array}$ & $\begin{array}{l}\text { Pengaruhh } \\
\text { Tidak } \\
\text { Langsing }\end{array}$ & $\begin{array}{c}\text { Pengaruh } \\
\text { Total }\end{array}$ \\
\hline Budaya Organisasi $\rightarrow$ Perilaku Anggota & 0.48 & & 0,48 \\
\hline Sistem tanggung renteng $\rightarrow$ Perilaku Anggota & 0,41 & & 0,41 \\
\hline Perilaku Anggota $\rightarrow$ Keamanan Usaha & 0,69 & & 0,69 \\
\hline Budaya Organisasi $\rightarrow$ Perilaku Anggota $\rightarrow$ Keamanan Usaha & & $\begin{array}{l}0,48 \times 0,69 \\
=0,33\end{array}$ & 0,33 \\
\hline Sistem tanggung renteng $\rightarrow$ Perilaku Anggota $\rightarrow$ Keamanan Usaha & & $\begin{array}{l}0,41 \times 0,69 \\
=0.28\end{array}$ & 0.28 \\
\hline
\end{tabular}

Signifikan $\alpha 5 \%$

\section{Pengujian Hipotesis}

Uji Hipotesis 1 : Lihat Tabel 2

Tabel 2

Pengaruh Budaya Organisasi dan Sistem tanggung renteng terhadap Perilaku Anggota

\begin{tabular}{lccc}
\hline \multicolumn{1}{c}{ Variabel } & $\begin{array}{c}\text { Koefisien } \\
\text { regresi }\end{array}$ & Nilai t & Nilai p \\
\hline Budaya Organisasi $\rightarrow$ Perilaku Anggota & 0,48 & 7,49 & 0,050 \\
\hline Sistem Tanggung $\rightarrow$ Perilaku Anggota & 0,41 & 6,41 & 0,000 \\
\hline$R \quad=0,70$ & & & \\
$R$ R Square $\left(\mathrm{R}^{2}\right)=0,48$ & &
\end{tabular}

Sumber: Data primer dioalah

Pada tabel 2 diperoleh nilai koefisien beta budaya organisasi sebesar 0,48 dan nilai t sebesar 7,49 dan nilai $\mathrm{p}$ sebesar 0,000 lebih kecil dari $\mathrm{p}=$ $0,05 \quad(\alpha=5 \%)$., Nilai koefisien sistem tanggung renteng adalah sebesar 0,41 dan nilai t sebesar 6,41 dan nilai $\mathrm{p}$ sebesar 0,000 lebih kecil dari $\mathrm{p}=0,05$ $(\alpha=5 \%)$. Budaya gotong royong (X1) yang diwujudkan dalam aplikasi sistem tanggung renteng (X2) memberikan pengaruh terhadap perilaku anggota (Y1), atau $\mathrm{X} 1+\mathrm{X} 2=\mathrm{Y} 1$. Kesimpulannya, hipotesis pertama yang menyatakan bahwa terdapat pengaruh yang signifikan antara budaya organisasi dan sistem tanggung renteng terhadap perilaku anggota Koperasi SBW Malang teruji.

Uji Hipotesis 2 : Lihat Tabel 3

Tabel 3

Pengaruh Perilaku Anggota terhadap Keamanan Usaha

\begin{tabular}{lccc}
\multicolumn{1}{c}{ Variabel } & $\begin{array}{c}\text { Koefisien } \\
\text { regresi }\end{array}$ & Nilai t & Nilai p \\
\hline Perilaku Anggota $\rightarrow$ Keamanan Usaha & 0,69 & 10,72 & 0,000 \\
\hline$R=0,69$ & & & \\
$R$ Square $\left(R^{2}\right)=0,47$ & & &
\end{tabular}

Sumber : Data primer, diolah

Pada tabel 3 diperoleh nilai koefisien beta budaya organisasi sebesar 0,69 dan nilai t sebesar 10,72 dan nilai $\mathrm{p}$ sebesar 0,000 lebih kecil dari $\mathrm{p}=$ $0,05(\alpha=5 \%)$, yang berarti bahwa perilaku anggota (Y1) berpengaruh signifikan terhadap keamanan usaha (Y2). Kesimpulannya, hipotesis kedua yang menyatakan bahwa terdapat pengaruh yang signifikan antara perilaku anggota terhadap keamanan usaha di Koperasi SBW Malang teruji.

Peneliti menemukan bahwa perilaku anggota berpengaruh terhadap keamanan usaha, yang berarti bahwa perilaku positif anggota memiliki kekuatan untuk meningkatkan keamanan usaha. Kemudian perilaku anggota yang terbangun dengan baik memberikan dampak terhadap keamanan usaha. Koperasi SBW Malang menetapkan bahwa unsur utama dari sistem tanggung renteng adalah adanya kelompok disampiang kewajiban dan peraturan. Tujuan dari sistem tanggung renteng adalah merubaha perilaku anggota menjadi lebih positif, pembentukan karakter manusia melalui interaksi yang baik antar manusia, menanamkan hak dan kewajiban sebagai anggota dan warga negara, dan sebagai sarana pendidikan perempuan. Semua tujuan, nilai, dan prinsip sistem tanggung renteng ini ditanamkan di dalam pertemuan kelompok secara rutin, konsisten, dan semua anggota menyadari bahwa pertemuan kelompok menjadi wadah pendidikan anggota yang paling efektif untuk membentuk perilaku anggota. Perilaku anggota yang baik menjadi kunci dari keamanan usaha, di mana anggota memegang nilainilai etis dari kejujuran dan keterbukaan. Semua permasalahan dimusyawarahkan secara jujur dan transparan. Demikian juga perkembangan usaha dan keuangan koperasi, disosialisasikan kepada seluruh anggota dengan jujur dan transparan. Semua keterbukaan ini membawa kehidupan berkoperasi yang positif, saling menjaga, dan saling memiliki sebagai satu keluarga besar.

Dalam penelitian ini, peneliti menemukan bahwa budaya organisasi dan sistem tanggung renteng berpengaruh terhadap perilaku anggota. Hal ini berarti semakin kuat budaya organisasi dengan pelaksanaan sistem tanggung renteng yang benar dan konsisten melalui pertemuan kelompok dapat meningkatkan perilaku positif anggota. Kehidupan di kelompok menjadi sarana utama tertanamnya budaya organisasi yaitu gotong royong, pelaksanaan sistem tanggung, dan terbentuk perilaku anggota.

Budaya gotong royong ini secara dominan memberikan pengaruh terhadap perilaku anggota dalam sistem tanggung renteng. Dalam sistem ini, anggota dibagi dalam kelompok-kelompok anggota yang diatur dengan sedemikian rupa sehingga tercipta kehidupan berkelompok yang kuat menjadi sebuah tingkatan manajemen tersendiri dalam berkoperasi. Upaya pembentuk perilaku anggota menjadi sesuai dengan budaya gotong royong dilakukan tanpa henti melalui aplikasi sistem 
tanggung renteng dalam kelompok-kelompok anggota. Aplikasi sisitem tanggung renteng dalam pertemuan kelompok menjadi pusat dari pendidikan, transaksi, pengendalian, pembentukan kepribadian, proses pengkaderan, dan pengembangan anggota secara langsung. Di dalam kehidupan berkelompok tersebut, anggota menerima banyak pembelajaran tentang nilai-nilai koperasi, prinsip-prinsip koperasi, nilai-nilai gotong royong, serta nilai dan prinsip sistem tanggung renteng. Tujuan sistem tanggung renteng di Koperasi SBW Malang yaitu memperbaiki perilaku manusia menjadi lebih positif.

\section{PENUTUP}

\section{Kesimpulan}

Kesimpulan dari penelitian ini beserta pembahasannya adalah sebagai berikut :

1. Budaya organisasi dan sistem tanggung renteng berpengaruh signifikan terhadap perilaku anggota yang berarti semakin kuat budaya organisasi dengan pelaksanaan sistem tanggung renteng yang benar dan konsisten dapat meningkatkan perilaku positif anggota.

2. Perilaku anggota berpengaruh terhadap keamanan usaha, yang berarti bahwa perilaku anggota memiliki kekuatan untuk meningkatkan keamanan usaha.

\section{DAFTAR PUSTAKA}

Agus Indriyo, Gitusudarmo dan Basri, (2002), Manajemen Keuangan. Yogyakarta:BPFE

Anwar Prabu Mangkunegara, (2005), Perilaku dan Budaya Organisasi. Bandung : Refika Aditama

Arikunto, S., (2006), Metode Penelitian Kualitatif. Jakarta: Bumi Aksara

Bintarto (1980), Gotong Royong Suatu Karakteristik Bangsa Indonesia. Yogyakarta. PT. Bina Ilmu Surabaya.

Dewanto \& Sonhaji, (2018), Strategic Plan Preparation Based On Values Of Cooperatives. IJBMI, Vol. 7)

Ignatius, Wursanto, (2003), Dasar-Dasar Ilmu Organisasi, Andi Yogyakarta. Yogyakarta

Kasiram, Moh. ,(2008), Metodologi Penelitian. Malang: UIN-Malang Pers.

Kasmir, (2008), Analisis Laporan Keuangan, Rajawali Pers, Jakarta.

Kitab Undang-Undang Hukum Perdata Republik Indonesia Pasal 1278, 1293.

Laporan Pertanggungjawaban Pengurus dan Hasil Pengawasan Pengawas Koperasi Setia Budi
Wanita Malang Jawa Timur Tutup Tahun Buku 2014, 2015, 2016, 2018.

Laporan Tahunan Kementerian Koperasi Dan Usaha Kecil Dan Menengah Tahun 2015

Koperasi SBW Malang, (2017), Modul Pelatihan TR untuk Anggota,

MPR RI, (2018), Materi Sosialisasi Empat Pilar.

Muchtar, Irsyad. (2012). 100 Besar Koperasi Indonesia 2012, Peluang dan Infopasar, Jakarta.

Munkner, Hans-H. (1997). Masa Depan Koperasi. (Djabarudin Djohan, Trans.). Dekopin-ICA, Jakarta.

Notoatmodjo, Soekidjo. (2003). Ilmu Kesehatan Masyarakat : Prinsip-prinsip Dasar. Jakarta : PT. Rineka Cipta.

Notulen Rapat Anggota Koperasi Setia Budi Wanita Malang Jawa Timur, 2017

Pasya, Gurniwan K. (1987). Gotong Royong dalam Kehidupan Masyarakat. Bandung: Universitas Pendidikan Indonesia.

Rivai, Veithzal. 2011, Manajemen Sumber Daya Manusia untuk Perusahaan: dari Teori ke Praktik, Jakarta : RajaGrafindo Persada

Sarmadi, A. Sukris. (2012). Membebaskan Postivisme Hukum Ke Ranah Hukum Progresif (Studi Pembacaan Teks Hukum Bagi Penegak Hukum). dari Jurnal Dinamika HukumVolume 12 Nomor 2.

Sekretariat Jenderal MPR RI, (2013), Pancasila.

Soedjono, Ibnoe. (1997). Koperasi dan Pembangunan Nasional, PIP-Dekopin, Jakarta.

Soedjono, Ibnoe. (2001). Manajemen Profesional Berdasarkan Nilai-nilai dalam Koperasi, LSP2I, Jakarta.

Sudjana, Nana dan Ibrahim, Penelitian Dan Penilaian Pendidikan, Bandung: Sinar Baru Algesindo, 2001

Sugiyono. 2012. Metode Penelitian Kuantitatif Kualitatif dan R\&D. Bandung: Alfabeta.

Suriasumantri, S. Jujun, (2002), Ilmu dalam perspektif moral, sosial dan politik, Gramedia, Jakarta, 2002

Tunggal, Amin Widjaja. 2010. Teori dan Praktek Auditing. Jakarta: Harvarindo.

Untari, Sri dan Dewanto, Deddy Satya. (2008). Sejarah Koperasi dan Sistem Tanggung Renteng, Koperasi Setia Budi Wanita, Malang.

Setyo, Braman, (2019), //bisnis.tempo.co/read/1208865/lpdbkumkm-tertarik-pola-tanggung-renteng

Damanik, Abdul Kadir, (2015). Bakal dibekukan Pusat, Jatim Gandoli 62.800 Koperasi Mati Suri., Surya.co.id, 23 Februari 2015 
Jurnal.id/id/blog/mengenal analisa ratio keuangan, 2018.

Kopkuninstitute.org/portfolio(2016)/tanggungrenteng-sebagai-tata-nilai-dan-sistem-didunia-koperasi

Pangestuti, Tri Widyani. (2017). Mati Suri, 100 izin Koperasi di Kota Malang Bakal dibekukan. Jatimtimes.com.2017.

Visi Kemenkop UKM, 2015, (http://pembiayaan.depkop.go.id/index.php/ public/visi

Wikipedia, Perilaku.

Zahiraccounting.com/id/blog/rasio keuangan, 2018).

\section{Profil Penulis}

1. Savitri Sartono, S.E., M.M, Keilmuan Manajemen, Universitas Merdeka (UNMER) Malang, J1. Terusan Dieng No. 62-64 Klojen, Pisang Candi, Kec. Sukun, Kota Malang Jawa Timur - 65146 Email : savitri2563@gmail.com

2. Dr. Hariyanto Respati, SE.,MM, Fakultas Ekonomi dan Bisnis, Universitas Merdeka Malang, Indonesia. 